\title{
Anglo-Arab Literatures: Enmeshing Form, Subverting Assignation, Minorizing Language
}

\section{Claire Gallien}

\section{(2) OpenEdition \\ Journals}

Electronic version

URL: https://journals.openedition.org/ces/4589

DOI: $10.4000 /$ ces.4589

ISSN: 2534-6695

Publisher

SEPC (Société d'études des pays du Commonwealth)

\section{Printed version}

Date of publication: 1 April 2017

Number of pages: 5-11

ISSN: 2270-0633

\section{Electronic reference}

Claire Gallien, "Anglo-Arab Literatures: Enmeshing Form, Subverting Assignation, Minorizing Language", Commonwealth Essays and Studies [Online], 39.2 | 2017, Online since 03 April 2021, connection on 04 June 2021. URL: http://journals.openedition.org/ces/4589 ; DOI: https://doi.org/ $10.4000 /$ ces.4589

\section{(c) $(1) \odot$}

Commonwealth Essays and Studies is licensed under a Licence Creative Commons Attribution - Pas d'Utilisation Commerciale - Pas de Modification 4.0 International. 


\section{Anglo-Arab Literatures Enmeshing Form, Subverting Assignation, Minorizing Language}

When discussing the prose of Franz Kafka and proposing to read it as a case of "minor literature," Gilles Deleuze and Félix Guattari guarded against a possible misconception of the term "minor." "A minor literature," they explained, "is not the literature of a minor language but a literature a minority makes in a major language" (116). For obvious reasons, this resonates with the literature discussed in this special issue - the first of its kind in France - of Commonwealth Essays and Studies. Indeed, the basic definition often given for the Anglo-Arab corpus is a set of texts written by a minority (Arab) in a major language (English). Some critics endorse this definition (Nash 11-2), while others regret it and the restrictions that ethnicity imposes on the corpus (Gana 29-30), but both sides agree on its perimeter.

Deleuze and Guattari did not stop with this initial statement but swiftly moved on to indicate that Kafka was of particular interest to them for his "minor use" of literature while writing in "the major language" that German represented for him and the Bohemian Jewish community in which he grew up. The "minor use," which certain writers force on a major language, plugs their literature directly into the political. It creates a field of tension, if not a battlefield, in which literature in the minor mode may chip at language, gradually hollowing it out, and "spin it along new revolutionary lines" (19). In other words, Deleuze and Guattari are not concerned about how a minor literature may rally the majority group but reflect on the conditions necessary to "wrest a minor literature from our tongue" (19).

This introduction and the volume as a whole represent an attempt to re-think AngloArab literatures outside the box and to propose that they hold more for readers than a pre-packaged corpus responding to the identification of a demand for exoticism and, in the post-9/11 context, for knowledge of the Muslim/Arab Other. I suggest it participates but also crucially escapes the capitalist logic of what Graham Huggan referred to as the marketable margin, and argue that a definition restricting it to a popular subbranch of diasporic or postcolonial literatures would be fundamentally flawed. Rather, I aver Anglo-Arab writing be reclaimed as a literature that opens up a space of a becomingminor for English.

As a corpus, Anglo-Arab literatures cover any type of fictional and non-fictional writing whether in the form of prose, poetry, or drama, written in English by authors of Arab descent, but who do not necessarily live in an Anglophone country and who do not necessarily possess the American, British, Canadian, or Australian nationality. Similarly the degree of connection to the Arab country of "origin" and to Arabic languages, in the form of fus.h.á (classical and modern standard) and 'ammiyya (vernacular), varies significantly from one author to the next, depending on the desire and capacity of the author to maintain that link to the language. Even non-practitioners in the language do invariably retain connection to Arabic cultures and literary traditions. Most of these texts and performances belong to the categories of immigrant (Hassan), diasporic (Smail Salhi and Netton; al-Maleh; Hout), or minority/postcolonial (Gana; Moore) 
writing, as they predominantly recount of Arab migration experiences to the North/ West, Arab migrant/minority lives in the North/West, but also of the havoc wrought by Western military interventions, wars, and occupation in the Arab-speaking world. While recognising the practicality of using the tag, I also feel an all-too pressing need to pluralise the term literature and to warn against the dangers of ethnicising/essentialising and monolingualising the corpus.

As the articles collected for this issue demonstrate, Anglo-Arab literatures are to be conjugated in the plural since they defy assignation to one race, nation, or language. The articles are based on the awareness of the variety of historical, social, cultural, and linguistic contexts in and through which authors navigate. Some of them write only in English, but still use Arabic as their mother tongues. Some do not use Arabic at all some write indifferently in English and Arabic, others prefer Arabic for certain topics, genres, formats, and English for others. English may be chosen or self-imposed, as when writers face censorship. It may be considered as more or less porous to the Arabic lexicon, syntax, and prosody, and be used naturally or with some degree of anxiety. Without a doubt, the choice of English carries meaning and has consequences. Writing in English testifies to the domination of the latter as a global language. It also necessarily selects a readership, imposes a notion of what its horizon of expectations should be, and defines the type of questions the narratives are likely to raise.

This being said, it must also be acknowledged that the words "choice" and "English" remain two very problematic terms. The notion of "choosing" to write in a language is far from obvious or natural and appears as the result of history (sometimes even personal history) and politics. Writers would concur that English is less chosen by than given to them and sometimes even imposed on them by the logics of globalisation and by educational systems which position English as the language of the cultural elite. For most Arabic writers today, consecration comes with English translation. They may also have "chosen" English strategically as a linguistic tool to write back to the Empire and be heard in it. This position is akin to the notion of "strategic essentialism" defined by Gayatri Chakravorty Spivak who states that minorities have to know how and when to use the identity politics card to further their demands and fight for their rights (Outside in the Teaching Machine 3).

Finally, what is implied in the "writing in English" is the "not writing in/with Arabic" or any other languages. It presupposes a conception of languages as discrete and exclusionary entities and implies monolingualism as default option (Young). On the contrary, what the articles gathered in this volume show are situations where English is reinvested as a language and as a literary tradition by writers with connections to the Arab world. Thus it may be argued that it is never absolutely clear what exactly is the English they are choosing, and that choosing English does not necessarily mean abiding by its rules. Rather, it may be chosen for purposes of destabilisation and crossfertilisation, through other grammars and other traditions. In this configuration, Arabic serves as "the revolutionary line" to demotion and, as a minority language working from within the English polity, it blocks any neat overlap between the language and the nation. It opens up new ways to think about personal, linguistic, and literary identities by refusing to define them as bordered entities and by choosing instead intersectional, temporal, less predictable, more disruptive and hence more creative modes of being. 
The poetry of Suheir Hammad in breaking poems is fruitful for thinking how grammatical English may not adequately convey the violence and brutality of life in Gaza, and how by hurting form and syntax the poet achieves a better transcription of reality. A language, i.e. English, cannot remain "proper" and be treated as such when it serves a global order decimating civilian populations abroad. Another illustration of the politics of language would be the co-presence of Arabic in English, as in Ahdaf Soueif's or Fadia Faqir's prose. Modes of writing, such as hurting the syntax or intersecting and co-mingling the languages, are linguistic strategies that allow for the emergence of alternative uses of language that destabilise hegemonic discourses and majoritarian conceptions of the world.

A second problem raised by the term "Anglo-Arab" is that of ethnicisation, by which I mean the fact that in order to write Anglo-Arab literature one has to be ethnically identified as Arab. Additionally, ethnicisation implies an expectation that Arab writers must write about Arab-related matters. This category appears to be extremely constricting and reduces the interventions of writers to community-related issues. Quite ironically, in a context where the opposition between imagination and reality, between the fictional and the non-fictional, falsehood and truth, is still culturally deeply rooted, even if held as scientifically invalid, the Anglo-Arab corpus tends to be read forensically as a purveyor of truth. ${ }^{1}$ This approach is dangerous for at least three reasons. First it disregards the politics and ideological positions of the writers themselves who always produce narratives from a certain standpoint and who are always necessarily embroiled in (sometimes conflicting) regimes of truth. Second, reading Anglo-Arab literatures ethnographically tends to deprive authors of the possibility of aesthetic interventions and by separating the aesthetical from the political, declares as nugatory any belief in the politics of form or fiction.

As a matter of fact, this type of ethnographic reading of Arabic literatures dates back to the early days of orientalism when the study of Eastern cultural productions was justified because it contained what was then regarded as useful information to understand the social and individual psyche of the Arabs. In other words, today's ethnographic reading of Anglo-Arab literatures amounts to a reproduction of an Orientalist agenda articulated in contemporary terms - the same that was applied to the Arabian Nights in the eighteenth century. Arab authors are not immune to Orientalism, especially since they depend on Western publishers and book markets. Instead of deconstructing Orientalist topoi, self-orientalised Middle-Easterners reproduce and confirm, since they are articulated by "natives," already existing prejudices (Lau; Lau and Mendes).

The authors in this volume spin out a different reading of the hyphen that links the "Anglo" to the "Arab" elements. It no longer functions as a block indexing a community, but as a suture that shows the stitches necessary in all identity construction, highlighting the tension and fragility involved in the process. It is both and at the same time affiliative and disjunctive and reminds us that identities are composed of pieces quilted together, which can be made and unmade. Our reading of "Anglo-Arab" is thus not

1. Anglo-Arab writers are generally very much aware and critical of this political approach to their writing. See for instance Sinan Antoon in an interview with Malcolm Forbes. 
ethnic but "affiliative," in the Saidian sense of the term. ${ }^{2}$ The construction of AngloArab identities and literatures are not to be understood as two blocks joined together at the seam so as to form a greater entity, but as the intersection, located in the hyphen, of various "routes" (Clifford). The hyphen functions less as a link than as a tension or a "distance that is not a safety zone but a field of tension" (Adorno 127). One of the methodological consequences of this is that many of the articles contained in this issue consider the Anglo-Arab corpus comparatively with other corpuses.

English writing by Middle Easterners is not a new phenomenon and can be traced back to the early twentieth-century diasporic literature of Khalil Gibran and Ameen Rihani. The publication of Anglo-Arab literature then boomed during the last decade, after 9/11 and the beginning of the war in Iraq in 2003 (Gana 1-5). This boom was supported by publishing houses which capitalised on a rise of the demand for Arab literature in English, purveying readers with some indigenous knowledge and perspectives on the people with whom Western countries were at war. Thus, the literary production of Arab writers, addressing a global audience in English, has largely been interpreted as a form of response or "writing back" (Ashcroft et al.) to the legacies of colonialism in the not-yet-postcolonial present (see for instance Ahdaf Soueif's second novel In the Eye of the Sun and Leila Aboulela's Lyrics Alley but also Suheir Hammad, Susan Abulhawa, and Selma Dabbagh on Palestine), to the politics of war (Hisham Matar's In the Country of Men and Anatomy of a Disappearance), and to mounting racism and Islamophobia in the West (Leila Aboulela's The Translator).

Thus Anglo-Arab literatures have made a long overdue entry (Loomba; Bernard et al.) into the postcolonial literary canon. The Arab(ic) element in them makes them supposedly better positioned (the inside view) and equipped to reflect on past and present forms of colonisation and coloniality, and in particular the colonial nature of Western interventions in the Middle-East and representations of Arab and Muslim people. Authors and critics alike, while highlighting the need not to restrict literature to the realm of politics, recognise the importance of these contributions as forms of counter-discourse to majoritarian views and stereotypes circulated in, amongst other places, Western mass media.

Additionally, participants in the fields of comparative literature, Arabic literature, and translation studies are taking the corpus in new directions and their perspectives renew with fascinating insights our perceptions of how Anglo-Arab writers intervene in contemporary literatures and societies. In particular, they scrutinize the relationship between language and power and emphasize the ways in which major publishing groups shape the literary market of translation. Numerous studies and reports emphasize the paucity of translation into English - with 3\% as yearly estimate for the average of all translations recorded in the British National Bibliography between 1992 and 2012 - and denounce the parochialism of English literature. This situation has a direct impact on the literary production of Arab writers. For instance, they may opt for self-translation or directly revert to English when writing fiction, in order to overcome the limitations

2. See for instance the definition Edward Said provided in his interview with Bruce Robbins for Social Text: "Worldliness was meant to be a rather crude and bludgeon-like term to enforce the location of cultural practices back in the mundane, the quotidian, and the secular. Affiliation is a rather more subtle term that has to do with mapping and drawing connections in the world between practices, individuals, classes, formations [...]. Above all affiliation is a dynamic concept; it's not meant to circumscribe but rather to make explicit all kinds of connections that we tend to forget and that have to be made explicit and even dramatic in order for political change to take place" (336). 
of the market of translated literature. Translation theory, especially on the notion of translation as creation (Benjamin), non-transferability, and non-equivalence between languages - what Barbara Cassin and Emily Apter called the "untranslatables," provides us with tools to rethink about the Anglo-Arab corpus and its relation with literatures in Arabic. In turn, this opens up new possibilities to consider the corpus from a comparative perspective, especially since writers are often cosmopolitan figures who have experienced exile or migration and are prone to identify with the figure of the other and find their inspirations in other literary traditions than the one in which they were born or in which they write. Writing in English on the edge or at the intersection with other languages and literary traditions constitutes a powerful means of creation, as well as a potent reminder that languages and literatures never belong (Derrida 39).

The contributions gathered in this volume place these stakes in the limelight. The first two by Jumana Bayeh and Geoffrey Nash question the scope and perimeters of action of the corpus. Bayeh's essay provides an overview of the recent and burgeoning developments in the field of Anglo-Arab criticism and assesses the widely used labels of "Anglophone Arab" or "Anglo-Arab" in these studies. It highlights the limitations of this "Anglophone Arab" designation and suggests that the critical concept of "diaspora" be applied instead. Nash's article focuses on the relation between Arab writers and Western publishing houses and calls into question the ability of Arab authors - whether their writings are translated from Arabic or inscribed directly in English - to undermine the stereotyping of Arabs and Islam and de-orientalise.

Sara Irving and Nora Parr read Anglo-Arab novels in comparison with Arabic literature, while Tahia Abdel Nasser suggests triangular comparisons with English, Arabic, and Spanish. Irving's article examines the portrayal of Arab-Jewish romance by Naomi Shihab Nye and Samir El-Youssef, two Anglophone authors of Palestinian origin. It reads these portrayals comparatively with those of Arabophone and Hebraeophone writers, arguing that differences stem in the main from their diasporic positionalities. Parr's article discusses the rendition into English of Adania Shibli's second Arabic novel and more particularly the removal of six love letters at the author's request, harnessing the politics of moving between languages in order to articulate the further removal of a national space. Finally Abdel Nasser's comparison of diasporic memoirs of return to Palestine in Arabic (Mourid Barghouti's Ra'aytu Ramallah), English (Najla Said's Looking for Palestine), and Spanish (Lina Meruane's Volverse Palestina) illuminates how Arab, ArabAmerican, and Latin American writers of Arab ancestry contribute to the redefinition of the genre and its particular role in the global cultural production on Palestine.

The last three contributions, by Sophia Brown, Irene Ramos, and Valeria Anishchenkova investigate how the choice of language impacts the contents, forms, and politics of writing. Brown's article seeks to examine the impact that urban space has had on the development of political consciousness in Ahdaf Soueif's autobiographical work. The article focuses on Mezzaterra: Fragments from the Common Ground (2004) and Cairo: My City, Our Revolution (2012) and argues that broad political affiliation and global solidarity emerge from the author's Arabic locale. Ramos's article discusses the increasing number of Palestinian theatre productions in English and unpacks the different strategies adopted to engage with the "burden of representation" imposed by global power structures while participating in them. The volume concludes with Anishchenkova's article which discusses several Arab-Americans' autobiographies in English, namely Edward Said's 
Out of Place, Ihab Hassan's Out of Egypt, and Leila Ahmed's A Border Passage, in order to highlight how certain language aspects - namely, Bakhtinian polyphony and hybridity reinvent and complicate any relation to language, genre, and identity.

This special issue aims to bring the Anglo-Arab corpus under the closer scrutiny of postcolonial scholars and to reclaim the term from simplified, monolingual, and ethnic uses in order to redirect it towards a strategy of becoming minor. Anglo-Arab authors navigating between languages both recognise the many labels and preconceptions placed on Arab identities and Arab writing, while establishing the inadequacies of the boxes to fit the subjects at hand. As editor and critic, I am less interested to define AngloArab literatures as texts in English by authors of Arab descent, than in considering the corpus as fundamentally relational and as a group of texts that evade monolithic and homogenous conceptions of belonging - to a language, a race, or a nation. I also believe that this is how the contributors to this volume conceived of the texts and performances under study. Anglo-Arab literatures belong to ecotonal zones where languages and literary traditions and inspirations, East and West, enmesh and produce rhizomatic structures of indistinguishable roots and stems. The Anglo-Arab corpus is minor when it produces its own Wörterflüchten (exits); when it shifts, deviates, and escapes assignation; when it unsettles the codes of Orientalism; when it refuses to decode and interpret and experiments with new and alternative literary directions instead.

Claire GALLIEN

Université Paul Valéry-Montpellier 3 (France)

\section{Works Cited}

Adorno, Theodor W. "82. Keeping one's distance." Minima Moralia: Reflections on a Damaged Life. Trans. E.F.N. Jephcott. London: Verso, 2005.

Al-Maleh, Layla, ed. Arab Voices in Diaspora: Critical Perspectives on Anglophone Arab Literature. Amsterdam: Rodopi, 2009.

AptER, Emily S. Against World Literature: On the Politics of Untranslatability. New York: Verso, 2013.

Ashcroft, Bill, Gareth Griffiths, and Helen Tiffin, The Empire Writes Back: Theory and Practice on PostColonial Literatures. London: Routledge, 1989.

Bernard, Anna, Ziad Elmarsafy, and Stuart Murray, eds. What Postcolonial Theory Doesn't Say. New York: Routledge, 2015.

Cassin, Barbara, ed. Vocabulaire européen des philosophies: Dictionnaire des intraduisibles. Paris: Seuil, 2004.

ClifFord, James. Routes: Travel and Translation in the Late Twentieth Century. Cambridge, MA: Harvard UP, 1997.

Deleuze, Gilles, and Félix Guattari. Kafka: Toward a Minor Literature. Trans. Dana Polan. 1975. Minneapolis: U of Minnesota P, 1986.ERRIDA, Jacques. Apprendre à vivre enfin: entretien avec Jean Birnbaum. Paris: Galilée 2005.

GanA, Nouri. "Introduction." The Edinburgh Companion to the Arab Novel in English. Ed. Nouri Gana. Edinburgh: Edinburgh UP, 2013. 1-35.

Hassan, Wail. Immigrant Narratives: Orientalism and Cultural Translation in Arab American and Arab British Literature. New York: Oxford UP, 2012.

Hout, Syrine. Post-War Anglophone Lebanese Fiction: Home Matters in the Diaspora. Edinburgh: Edinburgh UP, 2012.

Lau, Lisa. "Re-Orientalism: The Perpetration and Development of Orientalism by Orientals." Modern Asian Studies 43.2 (2009): 571-90.

Lau, Lisa, and Ana Cristina Mendes. Re-Orientalism and South Asian Identity Politics: The Oriental Other Within. London: Routledge, 2011.

Lazarus, Neil, and Priyamvada Gopal. After Iraq : Reframing Postcolonial Studies. London: Lawrence \& Wishart, 2006.

LoomBA, Ania, ed. Postcolonial Studies and Beyond. Durham, NC: Duke UP, 2005. 
Moore, Lindsey. Narrating Postcolonial Arab Nations: Egypt, Algeria, Lebanon, Palestine. London: Routledge, 2017.

Nash, Geoffrey. The Anglo-Arab Encounter: Fiction and Autobiography by Arab Writers in English. Bern: Peter Lang, 2007.

SAID, Edward. "American Intellectuals and Middle East Politics, Interview with Bruce Robbins, in Social Text, 1998." Power, Politics, and Culture. Interviews with Edward Said. Ed. Gauri Viswanathan. New York: Vintage Books, 2002. 323-42.

Salhi, Zahia Smail, and Ian Richard Netton, eds. The Arab Diaspora: Voices of an Anguished Scream. Oxford: Routledge, 2006.

SPIVAK, Gayatri Chakravorty. Outside in the Teaching Machine. New York: Routledge, 1993.

—. "Subaltern Studies: Deconstructing Historiography." Selected Subaltern Studies. Ed. Ranajit Guha and Gayatri Chakravorty Spivak. Oxford: Oxford UP, 1988. 3-34.

Young, Robert J. C. "That Which Is Casually Called a Language.” PMLA 131.5 (October 1, 2016): 1207-21. 